Article

\title{
Transforming the Conversation: What Is Liberation and from What Is It Liberating Us? A Critical Response to "Transforming Encounters and Critical Reflection: African Thought, Critical Theory, and Liberation Theology in Dialogue"
}

\author{
Justin Sands \\ School of Philosophy, North-West University Potchefstroom, Potchefstroom 2520, South Africa; \\ Justin.Sands@nwu.ac.za
}

Received: 5 June 2018; Accepted: 14 June 2018; Published: 19 June 2018

\begin{abstract}
The Religions special issue, "Transforming Encounters and Critical Reflection: African Thought, Critical Theory, and Liberation Theology in Dialogue," addresses the concern over the present postcolonial context in which African persons and societies find themselves. The issue attempts to gain a further understanding of this context through a dialogue between these three disciplines, but what emerges from this attempt? As a critical response to the issue as a whole, this article will reveal that each author presents different yet converging perspectives on the questions: 'what is liberation and from what are we being liberated?' This article begins by phrasing this question through Frantz Fanon's critique on the postcolony, where he sees that the same logic-what Schalk Gerber's article calls 'the logic of the colonizer' - is still employed in the postcolony. This article unpacks the entanglement created by this logic and how each author addresses it in different ways. Importantly, this is not a review of each article; rather, it seeks to reveal the narrative created by this interdisciplinary dialogue in order to further the conversation on oppression and liberation in an African context. In so doing, it reveals how each author addresses the concept of liberation or freedom and where they partially (or perhaps provisionally) agree that liberation entails embodied communal responsibility as being-with others, the importance of transparent dialogue, the need for new rationalities to enter the discussion of African self-determination, while also highlighting the dangers of appropriating these new rationalities when bringing them into an African context or when moving theory into praxis.
\end{abstract}

Keywords: decolonization; critical theory; liberation theology; African philosophy; African Theology; Postmodern philosophy; systematic theology; Postcolonialism; Joseph Cardinal Cardijn

\section{Introduction}

This article is an in-depth response to this Religions special issue since the conversations touched upon in this issue are themselves in medias res. "Transforming Encounters and Critical Reflection: African Thought, Critical Theory, and Liberation Theology in Dialogue" explores the founding principles of this conversation. What these articles reveal is a common thread running through the each respective discipline's questioning of what comes after the postcolony; what is next for African societies in particular but also for the global community at large. This thread essentially is a questioning of what is liberation and from what is it liberating us? 
Franz Fanon's Wretched of the Earth crystalizes this question when he discusses the concept of "national consciousness" and its leaders (the "national bourgeoisie") in African nations after their liberation from colonialization:

Independence does not bring a change of direction. The same old groundnut harvest, cocoa harvest, and olive harvest. Likewise the traffic of commodities goes unchanged. No industry is established in the country. We [i.e., those in the postcolony] continue to ship raw materials, we continue to grow produce for Europe and pass for specialists of unfinished products. ... Yet the national bourgeoisie never stops calling for the nationalization of the economy and the commercial sector. ... For the bourgeoisie, nationalization signifies very precisely the transfer into indigenous hands of privileges inherited from the colonial period.... For the dignity of the country and to safeguard its own interests, it considers it its duty to occupy all these positions. Henceforth it demands that every major foreign company must operate through them, if it wants to remain in the country or establish trade. The national bourgeoisie discovers its historical mission as intermediary. ${ }^{1}$

Fanon's aim here and throughout chapter three of Wretched of the Earth is to reveal how this so-called independence, or liberation, maintains the same power structure established by the colonialists. Moreover, this independence operates on the same logical foundations employed by the colonialists. The difference is that a group of the former colonized-the educated and well-connected 'national bourgeoisie' - replaces the European powers at the top. Yet still, as intermediaries to commerce and so-called development, they are still beholden to those European (or Western) powers. So the question arises again: is this liberation and from what are we being liberated?

In what follows, I will critically explore this questioning of liberation as it developed throughout the special issue. The special issue is divided into three parts, 'African Thought,' 'Critical Theory,' and 'Liberation Theology,' respectively, and what we will see is at once an expansion and tightening around the issue of liberation: The expansion, particularly in the Critical Theory section, will be toward the notion of freedom in a philosophical register, the questioning of liberation and from what opens itself to an inquiry on what it means to be free in the first place. The tightening results from the other two, book-ended sections which focus a notion of liberating freedom as at once a political and a spiritual concept within the African context. In what follows, I will show how interrelated each discipline's approach to the concept of liberation or freedom throughout the special issue.

The hope of "Transforming Encounters and Critical Reflection" was to re-examine the basis for these approaches in an attempt to find common ground for future discussions within academia and outside of it. It attempts to serve as a platform for future interdisciplinary dialogues in pursuit of better understandings of the world(s) in which we live and to push these theoretical understandings into more ethical and just praxes. Hence, before one can move to practically engage in liberation, we must have a more comprehensive concept of what is justice, what is freedom, and from what is this freedom liberating us.

\section{An African Perspective on the Concept of Liberation through Dialogue and the Critique of Logic}

Kelebogile T. Resane's article, "Transparent Theological Dialogue-Moseka Phofu Ya Gaabo Ga a Tshabe Go Swa Lentswe' (A Setswana Proverb)" explores a line of questioning liberation or freedom through an engagement with Christian dogma and the Christian struggle for liberation. ${ }^{2}$ The proverb-roughly translated as "one must fight impatiently for what rightly belongs to him or her"-is used by Resane "as a special appeal to theology to speak vigorously, vivaciously, and vividly"

Fanon (2005, p. 100), emphasis Sands.

Resane (2018). 
concerning the role of dogmatic, theological convictions in relation to the type of logic Fanon highlights in the quote above and throughout his oeuvre. However, in Resane's case, this focus is on the theo-logical convictions at play in this so-called independence and liberation. ${ }^{3}$ Although Resane does not cite Fanon, he is aware that this appeal can fall into the same dangers of Fanon's national consciousness "since this proverb [also] carries the meaning of patriotism, it can be ascribed theologically as promoting Christian apologia." ${ }^{\prime 4}$ As we shall see, Resane's concern against apologia links quite well with Schalk Gerber's description of the onto-theological constitution of metaphysics: for Resane, the suspicion against apologia resides in its defense of dogma and the faith, in Fanon's case it could be likened to a defense of national consciousness, and below Gerber reveals a similar concern through his dialogue between Achille Mbembe's and Jean-Luc Nancy's critiques of logical enclosures. ${ }^{5}$ In all three cases, one can see a suspicion against institutions and persons defending and upholding a certain logic, and the more one entrenches oneself into that logic the harder it becomes to see without it, especially if one is a part of the privileged few in power. An apologia of certain dogmas and their metaphysical structures becomes a sort of enclosure or exclusion of other concepts, hence Resane's apprehension against certain kinds of patriotism and theological dogmatism, which he extrapolates throughout the article.

Against this apprehension, Resane reads this proverb as a provocation to re-contextualize what we mean by dogma or theological convictions by calling for a more transparent dialogue. Transparency, here, is seen as "clear, unhindered honesty" on part of all dialogue partners which also entails an unhindered license to listen and to allow those who have been silenced to speak. ${ }^{6}$ For Resane, quoting Katrin Kusmierz, theology's role is to take up "the challenge of contributing to the shaping of common life" while knowing that this life "can only be meaningful and relevant if it takes into account its social, political, and economic context.." From here, one can see that Resane's appeal to theology is a contextual and political one, a position where Christian salvation-the impetus of several theological reflections-is placed upon questioning how one can experience that salvation in their own life. This entails liberation, but also cooperation through dialogue. As Resane argues, this type of theological reflection cannot exist on an island and must need "ecumenical cooperation." Resane continues in his article to explore how this cooperation, through transparency and dialogue, might unfold. Skipping ahead somewhat in his argument, he then explores the dogmatic, or rational and theo-logical, implications of such a dialogue. His final argumentations give a rationale for type of liberation theology that is based upon praxis and dialogue without giving up its core convictions, a liberation theology that is "consonant with Christian dogma and credo." ${ }^{\prime 9}$ Yet Resane has not forgotten the concerns against apologia and patriotism, rather, he finds that if theology emphasizes its dialogical, communitarian, and transparent roots, it can turn these concerns into at once warnings against past theological sins (a sort of hermeneutics of suspicion) while also being reminders of the purpose of the Christian Church and theology in general:

Theology must be chiefly concerned with reasoning about relation between God and God's creation (including humans), together with their ethical behaviors (Pietersen 2015, p. 120). Furthermore, theology as a moseka phofu must become patriotic in such a way that its prophetic utterances can be heeded by humanity in all spheres of life. ${ }^{10}$

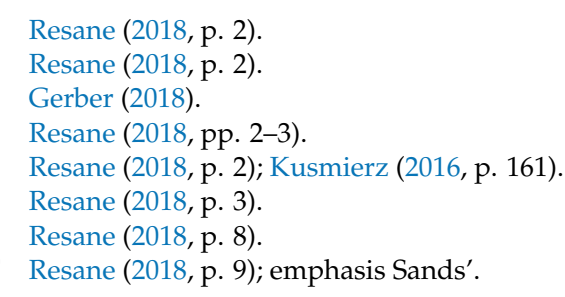


The patriotic thrust of moseka phofu becomes an inversion, and its apologetic thrust follows as well: theologians have often forgotten which side they should be on and their essential role in everyday life. They do not serve to 'protect their faith' and nor do they serve to 'uphold their society.' Their role is to better understand the relationship between God and all God's people, that the kingdom they serve is not on earth, that their patriotism should be focused on the Kingdom to come, one that involves all persons within all spheres and contexts. Therefore, transparency is needed for theologians to see these persons and spheres, to better understand their contexts and the logic(s) that suppresses others while also upholding the status quo.

Joel Mokhoathi's article, "From Contextual Theology to African Christianity: The Consideration of Adiaphora from a South African Perspective," seems to agree with the Resane's premise that contextual theological reflection in African communities must develop its own self-determination. Mokhoathi's first aim is to articulate that far too often this contextualization has been labelled as "syncretism" by theologians (mainly Western theologians), and therefore has been cast as an 'other' within the global Christian community: far too often Christianity in Africa is designated as "African Christianity," essentially a separation from the larger Christian community that falls in line with 'orthodox' dogmatic rationality. ${ }^{11}$ This dogmatic rationality that Mokhoathi highlights closes off ecumenical and communitarian dialogue partners. Although unintended (I imagine), Mokhoathi appears to have taken up Resane's call for transparent theological dialogue—moseka phofu—and his article deepens its implications by looking at the "things in between" (Adiaphora), which could be revealed through such transparent dialogues. ${ }^{12}$ His article explores the ways in which these dialogues were initially enclosed to uphold a theological Western rationality through mission work in Africa. He then continues to show how Christianity, in spite of this imposition from Western missionaries, grew within the contextualization and enculturation of Christian belief amongst and within African communities. This contextualization became the 'problematic' in African Christianity-the so-called syncretism - yet this happened not because Africans are uninterested in creeds or the essential teachings of Christianity, it happened because of the Western logic imposed by the missionaries cut off any dialogue with those whom they sought to teach the faith. In other words, instead of sharing their Christian beliefs to others and listening and learning from those others, they tried to impose en masse an unwavering metaphysics or logic that could not speak to the sensibilities of their African brethren and sistren. Mokhoathi argues thusly:

The implications therefore, of African theology, are that imported theologies do not sufficiently touch the hearts of African believers because they are couched in a language that is foreign to them (Muzorewa 1985, pp. 96-97). And, that the building of communication between Christianity and the African cultural and religious heritage is best left for African theologians because they know how best to contextualize Christianity in a manner that can fully communicate with their African cultural and religious heritage (Muzorewa 1985). Thus, in this argument, Christianity needs to assume a local and Africanised temperament, where it can be communicated in a language that Africans can understand and appreciate; and be articulated in a manner that can touch the hearts of Africans. In its reproduction, it is exclusively the task of African theologians to contextualize Christianity so that it may fully communicate with the African cultural context. As to how this can be done, it is not clear. But what is apparent is that the contextualization of Christianity has resulted in the emergence of African Christianity. $\left({ }^{13}\right)$

Mokhoathi's argument then goes on to map out the ways in which African culture and African Traditional Religions overlap with 'orthodox' (i.e., Western) Christianity and the ways in which 
so-called African Christianity develops its own theological rationale. Again, following Resane, Mokhoathi deepens our understanding of this transparent dialogue by unveiling what lies between 'African' and 'Western' Christianity. He locates where the convergences and divergences lay.

Relating back to our question concerning what is liberation and from what are we being liberated, his article enriches our understanding of the contextualities at play in liberation: Mokhoathi does not want an African church liberated from the Western theological tradition, nor does he want to suppress any Western theological influence on the African church. ${ }^{14}$ Rather, one of the aims in his paper is to show that the theo-logical rationale (and thus dogmatic or systematic formulation) of Christianity in Africa is more complex than mere syncretism or holding on to indigenous beliefs. It is interconnected with its pre- and post-missionary past, while also being connected to the global Christian community. Liberation, then, is not a freedom from something or a group, as in a separation from a particular Christian tradition. Liberation is again a contextual, ecumenical dialogue that opens Christian belief to all spheres of life. Both Resane and Mokhoathi find liberation to be communitarian. Liberation for them is dialogical, and through an emphasis on contextualities it seeks to address the Western rationality, a yoke, if you will, that is placed upon believers here-and-now, in this world, and their answer to liberation is to shed this yoke through solidarity, honest discussion, and an appreciation of others' traditions. They seek to reveal how this yoke and its rational justifications separates Christians, but it also separates all persons beyond Christianity, which becomes the focus of our next two authors.

Lawrence O. Ugwuanyi and Schalk Gerber's articles shift from this theological reflection toward African philosophical thought at large. In "Towards a Rational Kingdom in Africa: Knowledge, Critical Rationality and Development in a Twenty-First Century African Cultural Context," Ugwuanyi takes up the question of kingdoms and domains, but his attention is geared toward building an African self-understanding; one that is self-critical without being self-deprecating, one that is not fixed nor fixated on its past but is open for development. ${ }^{15}$ It is a different kind of kingdom-neither a heavenly one nor a totalitarian monarchy of reason-and although Ugwuanyi does not share the theological motivations of Resane and Mokhoathi, he continues their engagement with the question of which logic has dominated African rationality and what logic might come after it. His article, in its own way and which does not cite Fanon, still follows Fanon's critique that the national bourgeoisie perpetuate the rationality of their colonial predecessors. However, where Ugwuanyi diverges is that he seeks to move beyond Fanon's critique. Likewise, his argument aligns well with Resane's emphasis on transparent, vigilant dialogue. Almost as if he is dovetailing both of these notions into his own logical system, Ugwuanyi emphasizes an emergent rationality that is essentially contextual and African in its own self-determination:

My desired rational kingdom is one where different demands of reasoning will be realized in a complimentary manner [Sands: similar to Resane's and Mokhoathi's transparent dialogue] as against one where a strand or an aspect of reasoning will function to dominate and destroy others [Sands: similar to Fanon's critique]; where productive rational ethics will enable Africans to move beyond the current state of thinking which amounts to rational medievalism to one where critical but resourceful culture of modernity marked by innovative rationality define Africa's rational ethics. ${ }^{16}$

Ugwuanyi then gives a dialogical reading of the concept of reason-from its roots in Aristotle and Greek philosophy, to its contemporary, scientific formulations, to its recontextualization in contemporary Africa-all the while teasing out concepts and challenges to developing a rationality which would further African self-determination. Throughout, his aim is to present the conditions in which a "creative and critical rationalism [Sands: this includes being self-critical] is demanded by

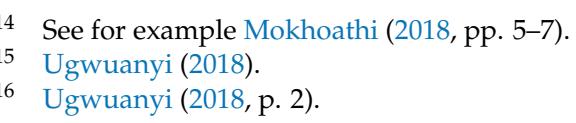


the African society" and possible avenues in which this demand can be satisfied. ${ }^{17}$ However, like all rationalities, there is the question of limitations; or, if you will, who can be citizens in this rational kingdom and what ideas could be (or could not be) included in this kingdom's constitution. Ugwuanyi is not naïve about this, which is why his reading of what rationality is and what it may become in an African context leads to two final sections that explore the developmental and cultural imperatives for building such a rational kingdom. Furthermore, one of his aims is to "problematize" the various traditions of rationality—both Western and African—in order to find a "desirable alternative."18

In a lot of ways, his article reminds me of Tsenay Serequeberhan's argument in The Hermeneutics of African Philosophy, where he argues that "the 'reconstructive challenge' of African philosophy is aimed at supplying a positive hermeneutic supplement to the concrete efforts under way on the continent. ... Paraphrasing Ngugi wa Thiong'o, one could say that this is the process of 'decolonizing the mind' or, with Cabral ... one can describe it as the struggle to 'return to the source.'"19 Time and space precludes me from going into detail, but Serequeberhan likewise goes through an intellectual history of philosophical discourses in Africa, hermeneutically exploring and teasing out the ways in which rationality has become the domain of the powerful. His argument concludes that African philosophy is in a double bind; it is in a discourse stuck between beginning a-new and returning to the sources-something highlighted through the so-called ethnophilosophy and Professional Philosophy debates spurred on by the likes of Paulin Hountondji. ${ }^{20}$ His response to this bind is similar to Ugwuanyi's in that he seeks a critical rationality (Serequeberhan's is rooted in hermeneutics) that explores the "lived circumstances" of the people in African communities and societies that is emancipatory at its heart; although Serequeberhan does not proclaim his emancipation through a metaphor of a kingdom, he does insist on a domain in which African thought and the cultures from which it springs can find self-determination. ${ }^{21}$

Returning to the question of what is liberation and from what are we being liberated, Ugwuanyi's article settles upon a liberation that allows African persons the freedom to express their own rationality, their own logic, through a critical reading of their traditions and the Western histories forced and forged upon those traditions. 'Liberation from whom' becomes the dominant rationality, the Western rationality, that in ways can be appropriated for African discourses but also must be resisted in some ways to allow space for African self-determination. Yet the question remains about whom and what is allowed in this kingdom, since kingdoms often require enclosures. Although Ugwuanyi follows Resane and Mokhoathi's call for dialogue, this question remains and it aligns well with Fanon's concern that those in power may still keep the same power structure of their former oppressors. Kingdoms still have kings, one could say, and who is the king of the African rational kingdom?

Schalk Gerber's article, “From Dis-Enclosure to Decolonization: In Dialogue with Nancy and Mbembe on Self-Determination and the Other," engages this foundational question through one of Fanon's contemporary interlocutors, Achille Mbembe, and the Continental philosopher Jean-Luc Nancy. What Gerber sees in arguments similar to the one Fanon makes above is what he calls "the logic of the coloniser." ${ }^{22}$ Gerber explores this logic and what it means to decolonization through two overlapping explorations: In Nancy's work, Gerber finds a contemporary European thinker who seeks to deconstruct the dominant logical thinking from within his own European context. Nancy's exploration of the metaphysical assumptions undergirding this logic, Gerber argues, can give us an understanding of how the consequence of this metaphysics for "the subject or social body is a matter of exclusion. That is the exclusion of everything that does not fit the identity of the Subject or Social

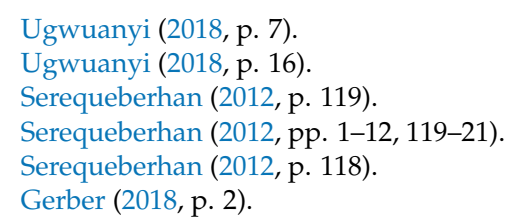


body, or in a reversal of terms, included as excluded." ${ }^{23}$ He links this with Mbembe's social critique, particularly in his seminal work On the Postcolony. I will refer the reader to Gerber's article for the sake of time, but his questioning of the logic of the colonizer, and his placing European deconstruction in dialogue with African decolonization shows the covalent trends in both subfields of philosophy. It does so while revealing that questioning the logical structures-which makes Fanon's critique of the national consciousness and its bourgeoisie possible-is inherently necessary before we can begin to understand the political and intellectual implications of liberation. ${ }^{24}$ This is especially so in a world dominated by Capitalism and an ever-interconnected (or, perhaps, entangled) world. ${ }^{25}$

Gerber's conclusion hinges upon the concept of a dis-enclosure as opposed to an enclosure or a logic (i.e., metaphysics) that necessarily excludes otherness to create order, or sense, of being-in-the world. Dis-enclosure, aligned with Mbembe's decolonization, is an attempt to present a logic where:

... every other is seen as an origin, from where the world is co-created; the world occurs at each moment of the world, as each time of Being in the realm of being-with of each time with every other time (Nancy 2000a, p. 20). Consequently, there is no set example, origin, or identity, according to which to model others. What it means to exist is not given or enforced on someone by another in reference to an abstract principle or identity. Rather, each time of Being constitutes a singularly unique origin of the world, making up the plurality of origins. Furthermore, the with of being-with, which lies between the I (subject) and the other, belongs to neither. No one possesses the monopoly on the question of existence with others. The with, instead, exposes one to an-other. ${ }^{26}$

Gerber's argument is an attempt to realize the community and commonality (the being-with, or Mitsein) of being-in-the-world. In a decolonial measure, this involves a re-thinking of our identity outside of the "logic of the coloniser" and turning to an identity that recognizes both the responsibility and the facticity that our beingness is amongst others; it happens in a shared world. ${ }^{27}$ Yet still, this responsibility requires recognition of the past and also for us to take "responsibility for ... the past, and also making sure that this kind of logic regarding race and the ontological status of the other does not continue in new forms in the future. It is then that the question of reparation can start to take place, of restoring the dignity of the other who co-exists in our shared world."28 Gerber's emphasis on being-with others opens us to a shared world, but the fact that he (rightly) argues that this necessitates a responsibility for the past to ensure a future that does not replicate this past seemingly appears to recognize Fanon's charge: that independence which perpetuates the power structure-or, better said, the logic of the colonizer-is not a true independence at all. In this way, Gerber's reading of Nancy and Mbembe continues the call for dialogue and for self-determination, but its emphasis on responsibility raises another concern: what is the relationship between responsibility and freedom? If we are responsible for the past— to make reparations for it as well as to not replicate it-in what way are we liberated? And, furthermore, if liberation or freedom means to emerge a-new with a self-determined rationality, in all of its communitarian and dialogical praxis, how and where does this responsibility limit this freedom? From whom or what are Africans being liberated if not the past transgressions imparted by colonialism?

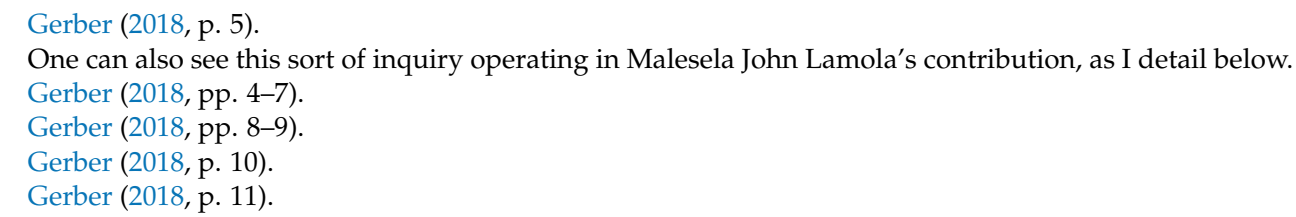




\section{A Critical Theoretical Engagement with Freedom in an Economically Dependent World}

This is where this special issue pivots toward an engagement with the concept of freedom and how one's (economic and political) engagement with others impacts one's freedom. Regarding this relationship, Abraham Olivier and Marcos Antonio Norris explore Jean-Paul Sartre's philosophy on different levels: Olivier questions what we mean by freedom or liberation concerning our historical situatedness; Norris, similar to Fanon and the authors discussed above, turns to the logic of the power structures; questioning what it means to have sovereignty in light of self-determination. Continuing the discussion, Mark Rathbone, similar to Gerber, returns to the concern over responsibility but situates it within an economic context by exploring how global Capitalism impacts our understanding of self-determination and accountability. Anné Verhoef then locates a particular lacuna in our concept of freedom or liberation, questioning whether our notions of these concepts might result in a deterministic outcome-which returns us back to Fanon's worry that independence in the postcolony only exchanges who yields the power yet does nothing but replicates the same logic of power used by the colonizer.

Olivier's article, "The Freedom of Facticity," initiates his analysis of Sartrean concept of freedom by asking of Sartre and his followers:

How free are we from situations, particularly ones in which we are subject to collective identification? More exactly, how free are we from the situations-places, environments, histories, others-that we inevitably belong to, and which subject us to collective identities? How free are we from identification in terms of others? How free are we to transform such identification ${ }^{29}$

To my mind, these questions align well with the contextual concerns and the implications of responsibility that I have highlighted already-particularly in the work of Mokhoathi, Ugwuanyi, and Gerber-but Olivier's questions give us a new perspective: freedom or liberation is not absolute; although Sartre claims that we are 'condemned be free' and that we maintain our freedom of choice regardless of circumstance, Olivier questions the ways in which our historico-cultural situation influences and sometimes limits this freedom. ${ }^{30}$ For example, one is not free to just choose to ignore the facticity of their whiteness while living in South Africa because of the privileges that come with whiteness still influence one's position in that world and influence what one can and cannot do. This comes into sharper focus in an African context, particularly when one reads Ugwuanyi's concept of a rational kingdom as African self-determination alongside Olivier, and notices that Ugwuanyi's concept of rationality necessitates that African persons and communities cannot hold on to an abstract concept of reason; it needs to be lived and embedded in their lives and interpersonal engagements. ${ }^{31}$

Olivier gives an in-depth reading of Sartre's notion of the "facticity of freedom" in order to arrive at his own understanding of freedom, what he calls "the freedom of facticity." 32 This freedom of facticity is based upon the "intentional heteronomy of freedom," meaning "that choices are not in the first place the manifestation of the nihilating power of consciousness, but rather that they are originally based on and shaped by the options offered in particular situations." ${ }^{33}$ Here, Gerber's employment of being-with others finds a dialogue partner, yet Olivier's intentions are to shift the focus from the self's awareness (or sense) of being-with others to otherness itself, or the object itself, and how this relation shapes the choices that one can and cannot make: "I [aim to] illustrate how choices between options are directed by objects in particular situations and their enabling conditions; second, more particularly, [I aim to illustrate] how choices between available options are learned in situations shared

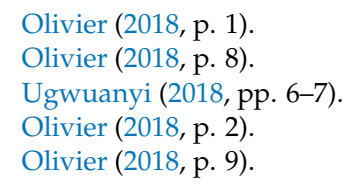


with others." ${ }^{34}$ Olivier's argument, as we shall see below, touches upon Mark Rathbone's concerns about how global economic factors shape our lives. ${ }^{35}$ Also similar to Rathbone, Olivier finalizes his argumentation through exploring Maurice Merleau-Ponty's concept of embodiment. For Olivier, Merleau-Ponty's concept of embodiment reveals how "we are 'born into' experiencing [the world] with its limits and options" and from this we are free to choose our own existential projects, such as joining a labor movement or political party: "freedom arises through such an existential project, through which, together with others with whom I share a past and present, I give my life direction." 36 Where Olivier diverges from Merleau-Ponty is that he does not see one's situatedness and one's freedom as "two poles of tension," but rather that they have a more symbiotic relationship where the situation offers to oneself choices which thus may or may not change one's situation. ${ }^{37}$ The final critical disagreement, and lynchpin to his argument, is that he finds "that freedom coincides with choice but [Olivier thinks] ... that facticity gives rise to choice in the first place." ${ }^{\prime 38}$

One can immediately see how Olivier's article intersects with those discussed above in that: First, he shares with our other authors an awareness of our historico-cultural situatedness (one could go as far as saying that, to varying degrees, all of the authors covered thus far share a Gadamerian appreciation of ones Wirkungsgeschichte Bewusstsein); Second, freedom or liberation entails dealing with this situatedness and its historical implications; and Finally, that dealing with these issues is also dealing with others-whether it is via transparent dialogue, developing a critical and contextual rationality for self-determination, or re-orienting oneself toward being-with others as the initiate to responsibility.

Marcos Antonio Norris' article, “Existential Choice as Repressed Theism: Jean-Paul Sartre and Giorgio Agamben in Conversation," transitions these agreements and returns back to the pressing concern of who holds the power in the logic (i.e. metaphysics) of freedom and liberation. ${ }^{39}$ Norris employs Agamben's notion of secularized theism over and against Sartre's concept of "sovereign decisionism," which he teases out of Sartre's struggle "to develop a political philosophy bereft of moral absolutes" and his concept of atheism which Marcos, referencing Kate Kirkpatrick, argues is "thoroughly Augustinian;" meaning that it was influenced by Augustinian notions of sin, being, and nothingness. ${ }^{40}$ Norris goes so far to argue that "Sartre secularizes Augustine to fit his atheistic worldview, professing the death of God at the same time that he advances a traditional (though secularized) idea [of being in relation to willing to be]." ${ }^{41}$ Marcos takes from this a concept of repressed theism in Sartre's phenomenology (and subsequently his concept of freedom and political philosophy) and in the next section he follows a line of reasoning similarly employed by Gerber by exploring and critiquing Sartre's understanding of metaphysics and its onto-theological foundation. Next, he places Sartre in dialogue with Giorgio Agamben to tease out the repressed theism he finds within Sartre's concept of existential authenticity (i.e., sovereign decisionism) to highlight how it maintains a sense of deification: "Sartre declares the end of morality while defending the metaphysical value of sovereign, self-originating choice. ${ }^{\prime 42}$ Relating this back to the discussion of what is liberation and from what are we liberated, Norris has shown that the logic of power is still at play when one takes up a Sartrean position of freedom; even if one is absolutely free to make one's own decisions, there is still an issue regarding power and sovereignty. If we return to Olivier et al.'s arguments about historical

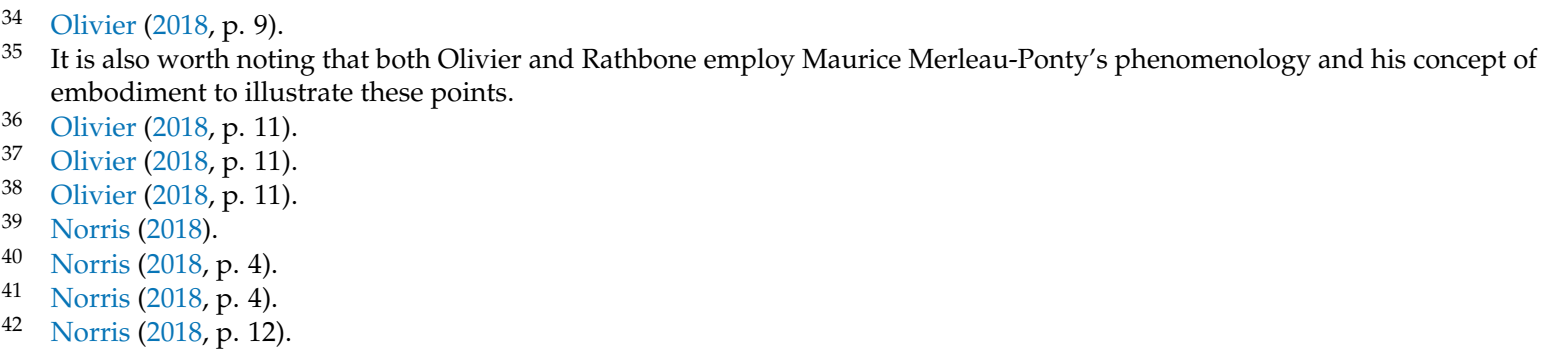


contextualities and that one is always amongst others, the question of who holds the power-or who gets deified in this logic of power à la Norris-still remains and one's freedom may come at the expense of others. Fanon's critique still emerges and the cycle replicates itself in this notion of freedom.

This is not to say that Sartre has no place in the conversation, but within the context of liberation alongside other selves and in an increasingly interconnected world, what this special issues' authors have found is that one's freedom must but understood as freedom with others. This recognition between both selves becomes a focal point for liberation: liberation necessarily requires a comprehensive understanding of being-with others, how history or the past situates that being-with into a present, contextual event, and how this contextual event requires transparent dialogue in order to address oppression and express (i.e., enact) a more just independence, thereby moving one's community closer to freedom or liberation.

Mark Rathbone's article, "Adam Smith, The Impartial Spectator and Embodiment: Towards an Economics of Accountability and Dialogue," deepens these findings by exploring how a community's historical situatedness is enveloped in a global Capitalist economy and his work explores pathways to making this economy both more accountable to and more equal for all those involved, particularly those within an African context. ${ }^{43}$ His exploration begins with Adam Smith whose master work, An Inquiry into the Nature and Causes of the Wealth of Nations, often overshadows his earlier work, The Theory of Moral Sentiments. Smith's Wealth of Nations, rightly or wrongly, is often seen as a founding text for Capitalism yet Rathbone argues that Moral Sentiments needs to be read alongside it to better understand how Smith envisioned his economic framework. ${ }^{44}$ In Moral Sentiments, Rathbone argues that Smith's concept of the "impartial spectator ... connects the individual to society. In this work, Smith's economics are far more complex than mere self-interest as the driver of commerce;" self-interest, here, is often misunderstood to be this driver to those who often cite Wealth of Nations as the essential text on Capitalism. ${ }^{45}$

Rathbone's tandem reading of both texts reveals that Smith envisioned a more communitarian economic system where the morality of commercial exchange held an equal importance to the economic gains resulting from such an exchange: for Smith, Rathbone argues, "self-interest functions within a socio-ethical framework that limits excess and narcissism." ${ }^{\prime 6}$ Rathbone first reviews how "Smith's work has often been misused to justify selfishness" and rebuffs this misuse through a critical reading of Smith's understanding of moral behavior. ${ }^{47}$ However, even though Smith envisioned a morality that "is directly linked to the socio-cultural system that condones behaviour, resulting in the joy of 'fellow-feeling' or mutual sympathy," Rathbone critiques this 'Smithian' position as being too deterministic. This determinism arises, for Rathbone, in Smith's "empiricist roots" that embeds moral development into an economy of exchange and a social system that approves of certain behaviors in support of maintaining said social system; one could say that the 'invisible hand' guides too much, approves too much, in order to maintain its primacy on regulating society. ${ }^{48}$ As we shall see, Anné Verhoef's article locates a similar type of determinism within our global social system through his reading of Slajov Žižek.

Skipping ahead in his argument, Rathbone employs Merleau-Ponty's phenomenology and his concept of embodiment to tease out how "the body ... is embedded in the interpretative process.... Therefore the situated subject, consciousness, and intentionality cannot be separated from the perceived environment or other people." ${ }^{49}$ After employing this concept of embodiment over and against the empiricism and idealism of Smith's time, Rathbone then uses it to show how our historico-cultural

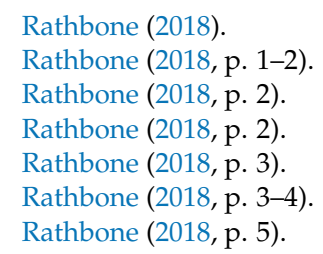


situatedness entails a limitation on our freedom and also a responsibility. Rathbone's argument may well remind us of Resane's and Mokhoathi's argument for dialogue and contextuality, Gerber's call for responsibility in being-with others, as well as Olivier's and Norris' critique of Sartre. Consider thusly:

The awareness of difference [amongst others and in our environments] highlights the possibility of other perceptions; because our perception of the world and others is inexhaustible and is not completely accessible to our consciousness and its intentionality, we remain free individuals. This freedom to act does not go beyond the existence of intersubjective relations between people; therefore, freedom goes hand in hand with accountability. The facticity of existence makes it impossible for empiricism to give way to idealism. We cannot be free in our minds with our self-determining consciousness if not also as bodily perceptive beings. For Merleau-Ponty, to escape self-determining consciousness, unlike Sartre's view that the consciousness is undetermined or "nothing", perceptions and freedom is always dependent on a particular situation. We are not determined to be an object in this world; however, there are limits to our freedom which require that we confront a situation and our assessment of it. We choose between various possibilities within a situation. There is no absolute freedom or absolute determinism, no idealistic norms for behaviour or behaviour that will gain approbation by others as envisioned by the impartial spectator. Rather, we are always embodied subjects within a particular situation and historical context provides the motivation for specific action. This is not a historicist reduction because the self remains different from others and the situation and can therefore act with freedom. ${ }^{50}$

Rathbone's final section, "Embodied Economics: Accountability and Dialogue," employs this reading of embodiment and its implications to freedom to suggest an economic framework that is based upon the fact that "the presence of others implies that the subject cannot simply act without recognition of others and accountability." 51 I refer the reader to the original article to see how Rathbone makes this argument. For our present purpose, his use of accountability functions in a similar way to the responsibility highlighted by Gerber, as well as Resane's argument that "theology as moseka phofu must become patriotic in such a way that its prophetic utterances can be heeded by humanity in all spheres of life." ${ }^{2}$ As we have seen up until now, the question of liberation and from what we are being liberated becomes an issue of the synonymous concepts of responsibility or accountability, which always already necessitates being-with others.

Verhoef's article, "Encountering Transcendence: Žižek, Liberation Theology and African Thought in Dialogue," returns to the issues of the logical, metaphysical structures undergirding postcolonial independence, which is similar to Fanon's critique and to the critiques highlighted throughout my reading of this special issue: namely, that the logic of independence or liberation entails a metaphysical structure (highlighted in Gerber and Ugwuanyi), which requires us to explore how this logical apparatus, or any one that replaces it, orders concepts and understandings through a conceptual framework. ${ }^{53}$ Verhoef employs the concepts of transcendence and immanence-as they are understood in African and Western thought ${ }^{54}$-in order to question whether these categories are "still needed and why? To what extent will the 'project of emancipation' (liberation) be furthered or hindered with the complete rejection of transcendence?" 55

50 Rathbone (2018, p. 6).

51 Rathbone (2018, p. 7), I quote at length since it shows the convergence of ideas shared by many of the authors in this special issue.

52 Resane (2018, p. 9); emphasis Sands.

53 Verhoef (2017).

54 Verhoef (2017, pp. 2-3)

55 Verhoef (2017, p. 4). 
Verhoef first explores the meaning and implication of transcendence, highlighting how transcendence has often been co-opted for ideologies of oppression. ${ }^{56}$ From here, Verhoef then explores Deleuze's concept of 'radical immanence' in order to see if a logical framework which proceeds without transcendence alleviates the ideological, oppressive tendencies that are often attributed to transcendence and/or in concepts of 'independence' like the one Fanon critiques is happening in the postcolony. His reading of Deleuze is informed by the work of Žižek, who eventually critiques Deleuzian radical immanence "for its inability to allow for human freedom.... this is ironic, because freedom is exactly what Deleuze intends to promote.... [Contrary to Deleuze and contrary to restoring a traditional transcendence-immanence framework, Žižek] emphasizes the need for epistemological and ontological transcendence, for a 'gap in the immanence' in immanence." ${ }^{\prime 57}$

From here, Verhoef goes on to articulate what Žižek intends with this gap in immanence. Skipping ahead for our present scope, the upshot of Verhoef's reading of Žižek is to show the ways in which Žižek's gap in immanence is "attuned" to liberation theology and African thought. ${ }^{58}$ Because of time and space, here I will only explore Verhoef's main point concerning liberation theology. ${ }^{59}$ For liberation theology, Verhoef sees the connection residing within liberation theology's "emphasis on social justice and on the emancipation of the poor and oppressed," where its concerns (contrary to, say, systematic or dogmatic theology) are more focused on "social action" than on "the beliefs and truths of Christianity.'" 60 Verhoef finds that "in its quest for freedom, Liberation theology can find in Žižek's 'gap of immanence' a space for insisting on the 'more', the excess, the 'imperceptible something', the 'minimal difference' between Christ-man and man." ${ }^{61}$ In other words, Verhoef thinks that Žižek's thinking may provide a way for liberation theology to keep its focus on 'liberation' without losing its 'theology' — as we shall see below, Malesela John Lamola's contribution to this special issue critiques liberation theology's use/appropriation of Marxist ideology critique, and here, in Verhoef's argument, we may find a way in which this Marxist emphasis on ideology and our emancipation from it does not overshadow or otherwise 'secularize' the theological foundation of liberation theology. Verhoef's aim in this article was not to completely reject transcendence but perhaps to reconcile it within a framework that is less inclined to become ideology; or, in the very least, to present Žižek as a dialogue partner for both liberation theology and African thought. Žižek's ideas-while critical of traditional logical and metaphysical frameworks-reveal new avenues to recontextualizing and reconsidering how we logically make sense of and construct our world.

Verhoef often employs the phrase "entry point" in the article and, returning to what I said about these conversations concerning liberation are in medias res, his suggestion of critiquing transcendent and immanent paradigms opens this conversation to new possibilities. The transparent dialogue expands, and the question of whom or what is included in the rational kingdom is re-examined. In this way, Verhoef's article connects with the ones previously discussed. Moreover, due to its exploration of ways in which each dialogue partner has something to learn from the other (Žižek, and, in general, liberation theologians and African philosophers), Verhoef also gives us means to transition to our third section, where the theoretical reflections gained thus far in this discussion are then weighed and measured for their practicality: we have partially settled on a communitarian, responsible, and dialogical understanding of liberation through self-determination alongside and along with other selves; furthermore, we have found that what suppresses liberation is often the

56 Verhoef (2017, pp. 4-5).

57 Verhoef (2017, p. 6), emphasis Verhoef.

58 Verhoef (2017, p. 11).

59 Verhoef does a strong job exploring the weltanschauung of African Traditional Religions and of African thought writ large. To get into how he sees the connection between Žižek's gap in immanence and African Thought would require either an all too simplistic summary or an extensive section on its own.

60 Verhoef (2017, p. 11).

61 Verhoef (2017, p. 11). 
logical, metaphysical framework which places the self's liberation over and against others. What this special issue turns to next is how this may become a possibility.

\section{The Issue of Praxis and Warnings of Entanglement, What Can Be Gained from These Discussions?}

Malesela John Lamola's article, "Marx, The Praxis of Liberation Theology, and the Bane of Epistemology," begins our exploration of turning our theoretical reflections into praxis by questioning the notion of praxis itself within liberation theology. ${ }^{62}$ His concern for praxis focuses on the "epistemological break" within Marx's work and how it becomes a problematic for the practical and transcendent nature of liberation theology. ${ }^{63}$ Referencing Louis Althusser, Lamola explores how Marx's epistemological break between his initial Feuerbachian theological position, the "'humanistic' early Marx," to his "'materialist-scientific'" later writings is an overlooked problematic for liberation theologians who often employ this break to overlay Marxian critique of ideology and society with a Christian spirituality. ${ }^{64}$ "What are the ramifications of this praxis in theology," Lamola asks, "given that it arose out of Marx's epistemological break from speculative and contemplative thought typical of Hegel and Feuerbach during his discovery of dialectical-historical materialism?"65 This question is also important for African philosophy and theology, given that several philosophers and thinkers in Africa—such as Paulin Hountondji, Ernest Wamba-Dia-Wamba, Kwame Nkrumah, Leopold Senghor, amongst others-employ a Marxist theory of praxis for postcolonial liberation. ${ }^{66}$ For now, in order to keep our scope, we will continue only with Lamola's concerns about this epistemological break.

Lamola's primary aim in the article is to question "the content and value of the concept of praxis as the interpretive frame of reference that emerged from the post-Feuerbachian Marx, and the implications of this frame for theology as a discipline and mode of knowledge that is premised on Transcendence. ${ }^{\prime 67}$ Essentially, his concern is whether a Marxian theory of praxis is compatible with theology as a whole-liberation theology is a sub-branch of Christian theological reflection, but does its emphasis on Marx sever it from the concept(s) of transcendence and therefore the larger theological doctrines that ultimately undergird Christianity? This was also a question for the Catholic Church in relation to Latin American liberation theology, even to the point of suppressing it. ${ }^{68}$ Yet through Lamola we see new a concern arise considering whether liberation theology's reliance (over reliance?) on Marx for its emphasis on praxis "assumes the form of a pre-Feuerbachian Hegelian theosophy." 69

Lamola unpacks this concern first through an in-depth reading of Althusser's analysis of Feuerbach's influence on early Marx and how Marx eventually transitioned into a materialist-scientific understanding of liberating the proletariat. ${ }^{70}$ This transition is where the epistemological break in Marx appears and Lamola specifically locates where Marx's concern "about the theoretical integrity of the universe of ideas" eventually leads him toward a suspicion against ideology; where theoretical logic turns into a political force or power. ${ }^{71}$ This again raises the concerns highlighted by Fanon and others in this issue, such as Ugwuanyi, Gerber, and Norris: what is the logic behind power, how does it replicate itself through ideology? But here, Lamola delves further into its epistemological implications

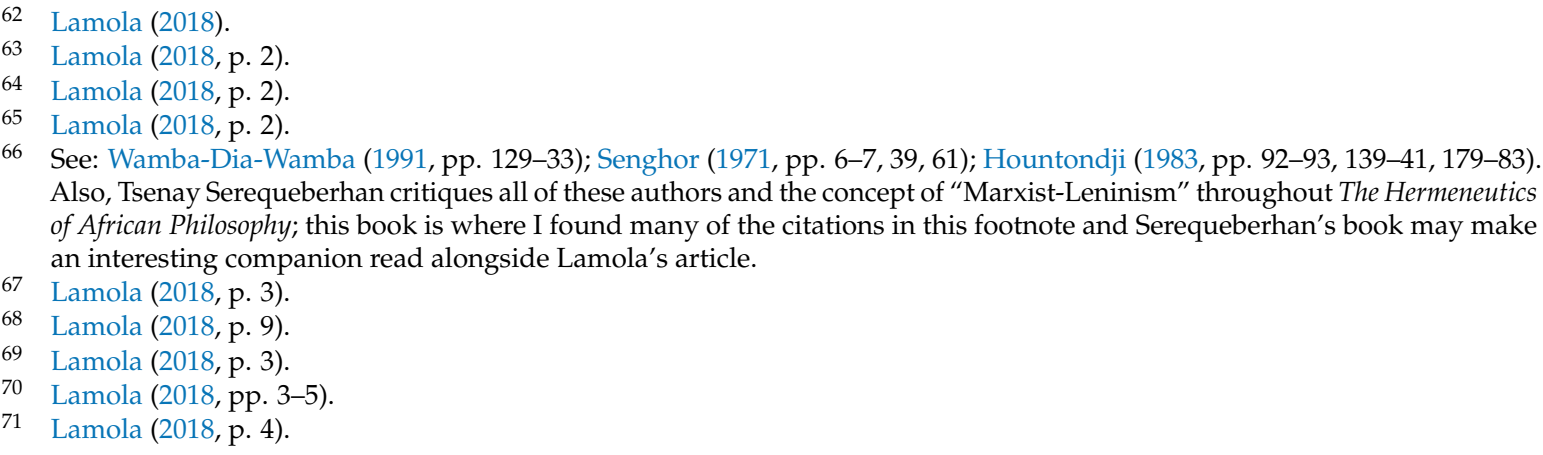


and how it creates not just oppression, but a means to understanding and being-in-the-world. Lamola's next section goes on to explore how Marxian ideology critique became central to Latin American theology, which we will save for the reader. For our present scope, what emerges from Lamola's work is Latin American theology's concept of "orthopraxis," where, quoting Gutierrez, the aim was "to recognize the work and importance of concrete behavior, of deeds, of action, of praxis in Christian life." 72

The concept of orthopraxis presented an epistemological understanding of the Christian faith through liberating works, which supplied the essential link between Marxian ideology critique and Christian theology. ${ }^{73}$ One can see here a connection to the questions raised above about the logical structures that undergird being-with others and also how it transforms into another ideology or metaphysics. Yet here, Lamola critiques it as a driving force for liberation in theology: does the liberation overtake the theology? This is Lamola's concern, and he goes on to give a few illustrative examples to show how this epistemology was enacted in liberation theology's history. ${ }^{74}$ What he finds is similar, yet contrary and perhaps critical of, Mokhoathi's argument for how 'African Christianity' and 'orthodox/Western' Christianity can overlap, dialogue, and mutually develop. This statement highlights Lamola's critique: "Liberation theology reduces social processes and experience into theological dogmas; the result is that praxis, transforming reality, is then left conceived as a riddled system of dogmatic inconsistencies, which are perpetually in search of some form of an esoteric resolution or another. The most pertinent example of this resultant theoretic confusion we find in the application of the doctrine of sin as theoria, an interpretive principle in political analysis." 75

Lamola's article is primarily a strong critique about the dangers of appropriation, which signals a warning bell to projects such as this special issue: when bringing into dialogue other theories, paradigms, disciplines, etc. what else are you unintentionally bringing into the conversation as well? When addressing the logic(s) of oppression through a multi-layered discussion, one must be vigilantly aware of all possible theoretical implications when moving toward praxis since it is undergirded by its own particular logic. Going back to Fanon, perhaps the national bourgeoisie did not realize that they were maintaining the same logic that brought them into colonialization. Through critical analyses such as Lamola's, we may become more aware of what we are unintentionally bringing with us in such dialogues, which, in Latin American theology of liberation, he says "develops mystical constructs out of historical contradictions;" one could easily connect the mystical here with Verhoef's concern for what happens to transcendence and/or immanence within these contradictions imparted by appropriating and adopting concepts/frameworks across disciplines or ideologies. As we shall see below through my contribution to the special issue, this may require us to find a provisional framework for such dialogues, so that certain concepts essential to each discipline/theoretical discourse involved are not forgotten, unintentionally assumed, or merely 'shaved away' to become retrofitted into a practical method of addressing oppression.

For now, in order to restore some optimism for us when exploring overlapping and intersecting dialogues on liberation and/or freedom, we turn to Ian Bekker's "Kairos and Carnival: Mikhail Bakhtin's Rhetorical and Ethical Christian Vision."76 Our concern is still what is liberation and from what are we being liberated, and alongside Lamola's warning against contradictory appropriations when building a theory for praxis, Bekker returns us to the question of embodiment through an exploration of Kairos and the Russian theorist Mikhail Bakhtin's theory of carnival, which holds a notion of embodiment different than the one employed by others in this special issue. When in dialogue with Lamola's article, one perhaps can see that Bekker contributes a possible connection to

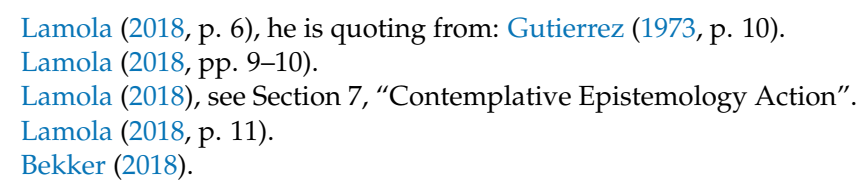


the epistemological break highlighted by Lamola's reading of Marx and his Christian appropriation. However, due to space and time, we will mainly explore how Bekker's article contributes to the concern over praxis in this special issue through God's action (or interaction) in human history through human agency itself. ${ }^{77}$

Bekker first gives an appraisal of the term kairos from within Christian theology and tradition. Here, he aims to highlight how, "on the one hand, we have a sense of kairos as a force or power that breaks through the expected or the repetitive ... through chronos or mechanical time.... On the other hand, kairos is also identified with the right proportion and symmetry; concepts that tend to be associated with order, balance, and continuity." ${ }^{18}$ Through this tension of breaking into mechanical (Greek/Western) temporality and the demand for balance and order, Bekker argues that we find "a connection with the ethical implications of kairos."79 This was especially taken up, Bekker finds, in Greek philosophy, where this "ethical dimension" becomes tightly linked to "phronesis," or practical wisdom, in the work of Plato and eventually Aristotle. ${ }^{80}$

What is interesting to Bekker is how this Greek concept of kairos and its ethical imperative, crystalized through its linkage to phronesis, is appropriated within a Christian context. Here, he explores how the Gospels used the term kairos when speaking of Jesus Christ's divinity and how this breaking into mechanical time by the divine develops an eschatological vision. Bekker then articulates how this becomes incorporated in Christian doctrine, especially in Paul Tillich and the South African liberation theologian, Albert Nolan. ${ }^{81}$

After reading Lamola's warning, what I find interesting is that what Bekker shows here is how appropriation and incorporation may be possible. It may be fruitful, even. Particularly when considering how kairos was not only employed to understand the possibility of how Christ-as-divine can enter the world but also how it is used to further articulate the eschatological and ethical implications of this divine in-breaking.

Yet returning back to our understanding of liberation/freedom as communitarian, responsible, and dialogical—as well as self-critical of the logics which undergird these concepts-Bekker's next section attempts to place his theoretical insight into praxis through Backhtin's notion of embodiment. Bakhtin was a Russian literary theoretician, steeped in a Classical philology as well as Kantian philosophy. ${ }^{82}$ What Bekker finds within his work is a connection, particularly to Tillich, between "finding a (phronetic, prudential) balance between form and dynamics ... a middle path between the extremes of individual subjectivism ... and abstract objectivism. ${ }^{\prime 83}$ One can perhaps see a connection here with Olivier and Norris' critique of Sartre, as well as their critique of freedom in light of embodiment. Moving ahead, Bekker locates that Bakhtin's 'middle path' through a sociological, ethical vision within his concept of carnival, or incarnation, is a rejection of Enlightenment rationalism that he found to be too speculative, too abstract, and therefore it cannot adequately address the ethical importance of being a human body in the world amongst other bodies. ${ }^{84}$ Carnival, Bekker warns us, can be interpreted in various extremes, which is worth a careful reading unto itself. ${ }^{85}$ However, skipping ahead and concerning our present scope, what Bekker sees is that carnival as embodiment and kairos, with its double function as divine action within chronological time and its desire for order, is an ethical vision of balance:

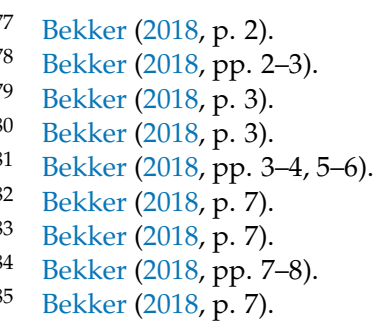


It is this ability to reconcile (and balance) the particular, the sensuous, and the changeable with the highest ideals that, I would argue, captures the essence of carnival, and is, I believe, the central motif of Bakhtin's complete work. ... In the same way the ancient concept of kairos captures not a primitive form of ethical relativism, but rather the necessity of sensitivity to the concrete and the historical; to the exercise of the virtue of prudence that cannot be captured by mechanically-applied ethical formulae. The Christian irruption of the divine into human affairs (i.e., kairos) captures a similar balance. The relevant irruption does not come to destroy or overthrow the Law, but rather to fulfill it. $\left.{ }^{86}\right)$

Bekker's reading of kairos and carnival, then, holds a tension between being-with others, being-in-the-world, and our theoretical (here, Christian) understanding of these relationships. Through Bakhtin, Bekker seeks a practical method for implementing our partial answers to the questions what is liberation and from what are we being liberated; in a theological register, it is a method of understanding the need to balance our historical situatedness, its subsequent baggage (if you will), and our need for a theoretical vision of that world. One may reject or accept Bekker's proposal in the article, but one can see within his proposal a focused desire to see how the theory highlighted in the articles above and the impetus to employ them through praxis need a balance or tension.

Importantly, Bekker's article is not a rebuttal to Lamola. Rather, as I see it, both work alongside each other in a hermeneutical tension between the positive and negative implications of placing theory into practice and how this reflexively changes our theory. Concerning Ugwuanyi's desire for a rational kingdom, both Bekker's reading of kairos and Lamola's critique against the contradictions inherent in a Marxist-based theology have a place in this kingdom. Both can aid us in seeing what rationalities can or cannot be brought into such a kingdom, and how thorough we need to explore the presumed logic(s) within these rationalities. Returning to Fanon's critique of the national bourgeoisie, one can see that his critique likewise looms over Bekker and Lamola's contributions.

My article, "Introducing Cardinal Cardijn's See-Judge-Act as an Interdisciplinary Method to Move Theory Into Practice," attempts to facilitate and progress this special issue's conversation, with its implicit/explicit tensions, by positing a possible framework for future interdisciplinary discussions. ${ }^{87}$ Lamola's critique of the contradictions that have arose within liberation theology's appropriation of Marxist critique impacted my decision to focus on what I find is the main problematic with interdisciplinary dialogues: How can we bring disciplines and theories into dialogue without entangling their various discourses and assumptions? How can we do so without creating a situation where each discipline has to abandon one of its essential or core concepts? Concerning liberation theology, how can it dialogue with critical theory, or a Marxist sociological analysis, without losing the 'theology' that orients its idea of liberation? Or, conversely and as addressed by Resane and Mokhoathi, how can African philosophy and theology dialogue with the Western Christian tradition or its ideological critiques of society without losing its African contextuality?

My proposal was to provisionally adopt a method crafted by Joseph Cardinal Cardijn, a Belgian priest whose work heavily influenced liberation theologians such as Leonardo and Clodovis Boff. Cardinal Cardijn's method, in short, employs three important meditations: first one must 'See' or embed themselves into the context they are engaging or the contexts of those whom one engages. The idea here, is not to overtake the other's perspective as one's one, in a sort of first naiveté, but in a second naiveté where one recognizes the distance between theirs and the other's context yet still tries to understand the situation from the other's perspective. ${ }^{88}$ From Cardijn's and liberation theology's perspective, this prevents an asymmetrical relationship that one especially sees within the "mentality held by many (usually) well-meaning activists that seem to know what is best for a community without

\footnotetext{
86 Bekker (2018, p. 9).

87 Sands (2018).

88 Sands (2018, pp. 3-4).
} 
actually understanding that community own its own terms." ${ }^{\prime 89}$ It is from this embedded reflection that one begins to understand the situation at hand in its own context, in how the other person sees it and how they wish to address it. From here, one builds with the community in which they are engaging, not on top of it or alongside it. From an interdisciplinary point of view, persons from each corresponding discipline begin to understand how the other discipline sees the issue at hand-in this case what is liberation and from what is it liberating us-and then begins to reflect upon how it differs from their own.

The next step, 'Judge,' is where one begins to formulate a plan of action or, in a dialogical attitude, a mutual understanding of how each person within the community can contribute to addressing the issue at hand. As I argue in my paper, the teleological impetus of this method (even before one gets to the 'Act' portion of the method) allows those in this community to focus their efforts on the given issue; rather talking past each other they can see where their own expertise/ability/discipline can contribute to this particular problem..$^{90}$ I find that such a framework may alleviate concerns over, or at least make transparent (pace Resane), one's assumptions and/or presumptions when in dialogue. By focusing the energy on the telos of such a dialogue, one can begin to see the strengths and limits to their discipline when addressing said telos. ${ }^{91}$

From here, once some sort of consensus is made, then the community can adequately 'Act' toward the telos. This is where praxis takes a primary focus. Importantly, acting, here, does not need to be in unison; each discipline or actor may choose how they can best contribute to addressing the situation at hand. Acting can take up many forms as it follows the discourses of the previous stages or reflections, but these previous reflections allow each actor to engage in his or her own way. Using liberation theology as an example, I argue thusly:

Liberation theology, as described above through Leonardo Boff and Clodovis Boff, moves from theory and theological reflection to praxis. Its teleological aim is toward a goal that is shared by its dialogue partners, African thought and critical theory. Therefore, it can employ its theological foundations concerning the need to satisfy both material and spiritual fulfillment for a sense of salvation, while also contributing insights to non-theological dialogue partners. It does not need to 'shave away', so to speak, its theological foundations to adequately help move theory toward praxis in this interdisciplinary dialogue; it merely needs to show how its theological foundations help inform the judgments and prescribed actions of its dialogue partners. ${ }^{92}$

Again and recalling the authors discussed above, one can see the call for transparent dialogue, a concern for each dialogue partner's historico-cultural situatedness (in academia, this also includes one's chosen discipline or method), and that such dialogues must maintain a tension between theories by focusing on how to move from dialogue to praxis. Importantly, I argued that my proposal for using such a method was provisional, that it may need to be further explored and adapted in order to function as a framework for dialogues such as the one in this special issue. Every method or framework has its limits, and as Lamola argues (as well as others in this issue) the limitations and contradictions of a given theory may become occluded when appropriated; creating a framework that is inherently contradictory. However, as I mentioned in the beginning of this critical response, the conversations in which we engaged in this special issue are in medias res, so perhaps after further reflection this method can help us engage in more fruitful conversations, to move out of talking past each other toward enabling us to act upon what we have learned.

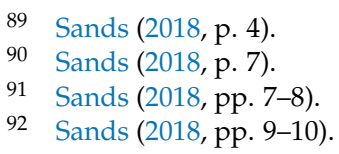




\section{By Way of Conclusion: Carrying the Conversation Forward}

This special issue was named "Transforming Encounters and Critical Reflection" for the very important reason that it is through encounters with others and through a critical reflection of those encounters that we might find a better understanding of being-in-the-world. Within an African context, this entails a discussion on the postcolony, decolonization, and the liberation from oppression. In this critical response, I have highlighted the narrative thread which connects the articles published but also to show how they are products of encounters. They are products of engaging in interdisciplinary dialogue, of questioning their discipline's own assumptions while also contributing ideas to their correspondents.

This revealed that each discipline within this African context is essentially questioning what is liberation or freedom, and from what are we being liberated? I employed Fanon's critique because, when reviewing all of the articles, it felt as if Fanon was hovering above the conversation. That his critique of the logic which upholds the (post)colony-initially published in 1961, even—is still with us and is still a concern for these three disciplines. Of course, this special issue did not 'solve' the problems and logic of oppression in the African context. Yet still, its questioning of the concept of freedom, logic, and the role of philosophy and theology in addressing this issue will be its main contribution to the ongoing conversations dealing with this oppression. Theory needs to become praxis, but how? Which theory? This issue highlighted how the concept of freedom is communal and historically situated, that it needs to address the past through communal responsibility, that it requires transparent dialogue, and that it needs to critically reflect upon the ways in which corresponding theories need to thoroughly explored before haphazardly being employed. The conversation over liberation and liberation from what continues, hopefully this special issue has aided in giving it a stronger direction.

Funding: This research was funded by the National Research Foundation of South Africa through a "Knowledge, Interchange, and Collaboration" grant.

Conflicts of Interest: The author declares no conflict of interest.

\section{References}

Bekker, Ian. 2018. Kairos and Carnival: Mikhail Bakhtin's Rhetorical and Ethical Christian Vision. Religions 9: 79. [CrossRef]

Fanon, Frantz. 2005. The Wretched of the Earth. Translated by Richard Philcox. New York: Grove Press.

Gerber, Schalk Hendrik. 2018. From Dis-Enclosure to Decolonization: In Dialogue with Nancy and Mbembe on Self-Determination and the Other. Religions 9: 128. [CrossRef]

Gutierrez, Gustavo. 1973. A Theology of Liberation: History Salvation and Politics. Translated by Inda Caridad, and John Eagleson. Maryknoll: Orbis Books.

Hountondji, Paulin J. 1983. African Philosophy: Myth and Reality. Bloomington: Indiana University Press.

Kusmierz, Katrin. 2016. Theology in Transition: Public Theologies in Post-Apartheid South Africa. Zuric: LIT Verlang $\mathrm{GmbH} \& \mathrm{Co}$.

Lamola, Malesela John. 2018. Marx, the Praxis of Liberation Theology, and the Bane of Epistemology. Religions 9: 74. [CrossRef]

Mokhoathi, Joel. 2018. From contextual theology to African Christianity: The Consideration of Adiaphora from a South African Perspective. Religions 8: 266. [CrossRef]

Norris, Marcos Antonio. 2018. Existential Choice as Repressed Theism: Jean-Paul Sartre and Giorgio Agamben in Conversation. Religions 9: 106. [CrossRef]

Olivier, Abraham. 2018. The Freedom of Facticity. Religions 9: 110. [CrossRef]

Rathbone, Mark. 2018. Adam Smith, the Impartial Spectator and Embodiment: Towards an Economics of Accountability and Dialogue. Religions 9: 118. [CrossRef]

Resane, Kelebogile Thomas. 2018. Transparent Theological Dialogue-Moseka Phofu Ya Gaabo Ga a Tshabe Go Swa Lentswe' (A Setswana Proverb). Religions 9: 54. [CrossRef]

Sands, Justin. 2018. Introducing Cardinal Cardijn's See-Judge-Act as an Interdisciplinary Method to Move Theory into Practice. Religions 9: 129. [CrossRef] 
Senghor, Leopold Sedar. 1971. The Foundations of 'Africanté' or Negritude and Arabité. Paris: Presence Africaine. Serequeberhan, Tsenay. 2012. The Hermeneutics of African Philosophy. New York: Routledge.

Ugwuanyi, Lawrence Ogbo. 2018. Towards a Rational Kingdom in Africa: Knowledge, Critical Rationality and Development in a Twenty-First Century African Cultural Context. Religions 9: 96. [CrossRef]

Verhoef, Anné Hendrik. 2017. Encountering Transcendence: Žižek, Liberation Theology and African Thought in Dialogue. Religions 8: 271. [CrossRef]

Wamba-Dia-Wamba, Ernest. 1991. Philosophy in Africa: Challenges of the African Philosopher. In African Philosophy: The Essential Rudings. Edited by Tsenay Serequeberhan. New York: Paragon House.

2018 by the author. Licensee MDPI, Basel, Switzerland. This article is an open access article distributed under the terms and conditions of the Creative Commons Attribution (CC BY) license (http://creativecommons.org/licenses/by/4.0/). 